\title{
In Vitro Culture and Rooting of Diospyros virginiana L.
}

Kaitlin J. Palla and Rochelle R. Beasley

Purdue University, Department of Forestry and Natural Resources, Hardwood Tree Improvement and Regeneration Center (HTIRC), 715 West State Street, West Lafayette, IN 47907

Paula M. Pijut ${ }^{\mathbf{1}}$

USDA Forest Service, Northern Research Station, HTIRC, 715 West State Street, West Lafayette, IN 47907

Additional index words. common persimmon, plant tissue culture, rooting, vitro

Abstract. The hard, strong, very close-grained wood of common persimmon (Diospyros virginiana L.; Ebenaceae) is desirable for specialty products such as golf club heads, percussion sticks, billiard cues, and for wood turnery. The edible fruit of cultivated varieties is sold as pulp for use in puddings, cookies, cakes, and custards. Persimmon is usually propagated by grafting. Own-rooted clonal persimmon could offer several advantages to specialty fruit growers such as elimination of grafting, graft incompatibility issues, and improved rootstocks for variety testing. Four mature, grafted (male and female) persimmon genotypes and one hybrid were used for nodal explant culture. Nodal stem explants were cultured on Murashige and Skoog (MS) medium containing $10 \mu \mathrm{M}$ zeatin, $3 \%(\mathrm{w} / \mathrm{v})$ sucrose, and $0.7 \%(\mathrm{w} / \mathrm{v})$ Bacto agar. Explants were routinely transferred to fresh medium every 3 weeks until shoot cultures were established. All nodal explants excised from grafted greenhouse plants produced at least one viable shoot. For in vitro rooting of microshoots, half-strength MS medium with $0,5,10$, or $15 \mu \mathrm{M}$ indole-3-butyric acid (IBA), $0.1 \mathrm{~g} \cdot \mathrm{L}^{-1} \mathrm{phloroglucinol,} 3 \%(\mathrm{w} / \mathrm{v})$ sucrose, and $0.7 \%(w / v)$ Bacto agar were tested with a 10-day dark culture treatment followed by culture in the light. Best rooting $(14 \%$ to $87 \%)$ was achieved on medium containing 5 $\mu M$ IBA for the common persimmon genotypes with means averaging from 0.5 to 3.9 roots per shoot. Ninety-one percent rooting with $5.3 \pm 2.6$ roots per shoot was achieved for the hybrid persimmon. Rooted plants were successfully acclimatized to the greenhouse.

Diospyros virginiana L. (Ebenaceae), also known as common persimmon, American ebony, or possumwood, is a deciduous, medium-sized tree (12 to $18 \mathrm{~m}$ ) native to the east-central and southeastern United States (Fig. 1A). Common persimmon is shadetolerant and prefers moist, well-drained, bottomland or alluvial soils but can thrive on almost any type of soil (Halls, 1990). Its deep taproot makes it useful for erosion control. The common persimmon is classified as typically dioecious, good fruit crops (Fig. 1B) are borne every 2 years with optimum fruit-bearing at 25 to 50 years of age. In

\footnotetext{
Received for publication 8 Feb. 2013. Accepted for publication 1 Apr. 2013.

We thank Jerome (Jerry) W. Lehman and members of the Indiana Nut Growers Association for partial financial support of this research. We thank Drs. Brian Maynard and Valerie Pence for their constructive review and suggestions for the improvement of this manuscript.

Mention of a trademark, proprietary product, or vendor does not constitute a guarantee or warranty of the product by the U.S. Department of Agriculture and does not imply its approval to the exclusion of other products or vendors that also may be suitable.

${ }^{1}$ To whom reprint requests should be addressed; e-mail ppijut@purdue.edu or ppijut@fs.fed.us.
}

the wild, the fruit is consumed by birds, deer, and small mammals. The hard, strong, even-textured, shock-resistant, close-grained wood (Fig. 1C) is desirable for specialty products such as golf club heads, percussion sticks, billiard cues, wood turnery, and veneer (Coladonato, 1992). Diospyros kaki, also known as Japanese or Oriental persimmon, is an important horticultural crop, whereas $D$. virginiana is considered a minor, but desirable, fruit tree and specialty wood product species. The edible fruit of cultivated varieties of common persimmon are sold as pulp for use in puddings, cookies, cakes, and custards. Persimmons are usually propagated by grafting (Morton, 1987). Own-rooted clonal persimmon could offer several advantages to specialty fruit growers such as elimination of grafting (alleviating seedling rootstock variation), graft incompatibility issues, and production of improved rootstocks for variety testing. In vitro propagation of common persimmon would be valuable for the development of commercial rootstocks for the nursery industry. The objective of this study was to develop an in vitro propagation protocol for four mature cultivars of common persimmon and one hybrid genotype. To the best of our knowledge this is the first report on in vitro culture of these cultivars of common persimmon and this hybrid.
Plant material. Four mature common persimmon cultivars (Diospyros virginiana) and one hybrid were used in this study. The main use of these cultivars was for the production of fruit for human consumption and for pulp processing. D127M is male, exhibits vigorous growth, is a good rootstock for grafting females, and is related to 'Dollywood'. Golden Supreme is female, produces large late-ripening fruit, and clear pulp. Szukis is male but displays bisexual traits, produces large midseason ripening fruit, is self-pollinating, and believed to be a seedling of 'Early Golden'. Claypool H118 is female, produces large early-ripening fruit, and clear pulp. The hybrid 'Rosseyanka', D. virginiana (seed parent) $\times D$. kaki (pollen parent), produces 5- to 7-cm fruit, is a cold-hardy Russian hybrid, and nearly seedless. Scion wood from each genotype was grafted onto seedling rootstock of field-grown common persimmon.

In vitro shoot culture establishment. All actively growing stems from 2-year-old grafted stock plants growing in the greenhouse were surface-disinfected in $70 \%(\mathrm{v} / \mathrm{v})$ ethanol for $30 \mathrm{~s}$, then $15 \%(\mathrm{v} / \mathrm{v})$ bleach solution (5.25\% sodium hypochlorite) for $15 \mathrm{~min}$, followed by four rinses in sterile, deionized water. Single-node stem explants were cultured on Murashige and Skoog (1962) basal medium (M499; PhytoTechnology Laboratories, Shawnee Mission, KS) plus organics containing filter-sterilized $10 \mu \mathrm{M}$ zeatin, 3\% $(\mathrm{w} / \mathrm{v})$ sucrose, and $0.7 \%(\mathrm{w} / \mathrm{v})$ Bacto agar (No. 214030; Becton Dickinson) in Magenta GA-7 vessels (Magenta Corp., Chicago, IL; $50 \mathrm{~mL}$ medium). The $\mathrm{pH}$ of the medium was adjusted to 5.8 before autoclaving. Three replications with 12 explants per replication for each genotype were conducted. Nodal explant cultures were maintained under a 16-h photoperiod provided by cool-white fluorescent lamps $\left(80 \mu \mathrm{mol} \cdot \mathrm{m}^{-2} \cdot \mathrm{s}^{-1}\right)$ at $25 \pm$ $2{ }^{\circ} \mathrm{C}$ and transferred to fresh medium every 3 weeks until a single shoot elongated from the bud. The individual, elongated microshoots from each original nodal explant were routinely cultured on the same medium with $5 \mu \mathrm{M}$ zeatin and routinely micropropagated through nodal sections to increase the number of clonal shoots available for rooting trials.

Rooting of microshoots and acclimatization of plants to the greenhouse. Microshoots ( 2 to $3 \mathrm{~cm}$ in length) were induced to form roots on half-strength MS medium with $100 \mathrm{mg} \cdot \mathrm{L}^{-1}$ phloroglucinol; $0,5,10$, or $15 \mu \mathrm{M}$ IBA; $3 \%(\mathrm{w} / \mathrm{v})$ sucrose; and $0.7 \%(\mathrm{w} / \mathrm{v})$ Bacto agar in Magenta GA-7 vessels (one shoot per vessel; $50 \mathrm{~mL}$ medium). The $\mathrm{pH}$ of the medium was adjusted to 5.8 before autoclaving. Three to five replications with eight shoots per treatment for each genotype were conducted. Cultures were incubated at $25 \pm$ $2{ }^{\circ} \mathrm{C}$ in darkness for $10 \mathrm{~d}$ to induce rooting and then transferred to a $16-\mathrm{h}$ photoperiod provided by cool-white fluorescent lamps ( 80 $\left.\mu \mathrm{mol} \cdot \mathrm{m}^{-2} \cdot \mathrm{s}^{-1}\right)$ at $25 \pm 2{ }^{\circ} \mathrm{C}$. The number of shoots forming roots, number of roots per shoot, and root length were recorded after 4 
weeks in the light. Rooted plantlets were gently removed from the agar medium and potted in $10-\times 10-\mathrm{cm}$ plastic pots containing a moist autoclaved potting mix containing $65 \%$ peatmoss, perlite, vermiculite, starter nutrients, wetting agent, and dolomitic limestone (Fafard Super-Fine Germinating Mix, Agawam, MA) and grown under a 16-h photoperiod $\left(80 \mu \mathrm{mol} \cdot \mathrm{m}^{-2} \cdot \mathrm{s}^{-1}\right)$ at $25 \pm 2{ }^{\circ} \mathrm{C}$. All agar was removed from the roots before transplanting. Pots were placed in $3.8-\mathrm{L}$ plastic zip-lock bags to provide a high relative humidity and had four holes punched below the zip-lock to allow for air exchange. The bags were gradually opened over a period of 2 to 4 weeks in the culture room to allow plantlets to acclimatize to ambient conditions. Plants were watered once a week until the bags were fully opened and then watered as needed. After $\approx 4$ to 6 weeks, plants were transferred to the greenhouse. Plants were irrigated as necessary with acidified water containing a combination of two watersoluble fertilizers $(3: 1$ mixture of $15 \mathrm{~N}-2.2 \mathrm{P}$ $12.5 \mathrm{~K}$ and $21 \mathrm{~N}-2.2 \mathrm{P}-16.6 \mathrm{~K}$, respectively; The Scotts Co., Marysville, $\mathrm{OH}$ ) to provide the following (in $\mathrm{mg} \cdot \mathrm{L}^{-1}$ ): 200 nitrogen, 26 phosphorus, 163 potassium, 50 calcium, 20 magnesium, 1.0 iron, 0.5 manganese and zinc, 0.24 copper and boron, and 0.1 molybdenum. Nitrate form was $76 \%$ of nitrogen provided. Irrigation water was supplemented with 93\% sulfuric acid (Brenntag, Reading, PA) at $0.08 \mathrm{~mL} \cdot \mathrm{L}^{-1}$ to reduce alkalinity to $100 \mathrm{mg} \cdot \mathrm{L}^{-1}$ and $\mathrm{pH}$ to a range of 5.8 to 6.2 .

Statistical analysis. SPSS (software Version 17) (SPSS, Inc., 2009) was used to analyze rooting data. An analysis of variance (ANOVA) was performed using the General Linear Model procedure on the individual replicate means by treatment for the number of shoots forming roots, number of roots per shoot, and root length. If the ANOVA indicated statistical significance, a Duncan's comparison test with an alpha level of 0.05 was used to distinguish the differences between treatments.

\section{Results and Discussion}

Common persimmon microshoots from four mature genotypes (D127M, Golden Supreme, Szukis, and Claypool H118) and one hybrid 'Rosseyanka' genotype were successfully established in vitro after 2 to 3 months culture on MS medium with $10 \mu \mathrm{M}$ zeatin (Fig. 2A-B). All of the nodal explants excised from the grafted greenhouse stock plants produced at least one shoot for continuous micropropagation. MS medium with zeatin has previously proven to be one of the best basal medium and plant growth regulators for supporting $D$. kaki in vitro shoot growth (Cooper and Cohen, 1985; Fukui et al., 1989; Tao and Sugiura, 1992; Hiyoyuki Chijiwa, personal communication). Cooper and Cohen (1985) reported that MS medium with $4.56 \mu \mathrm{M}$ or $13.69 \mu \mathrm{M}$ zeatin produced the best shoot growth from nodal explants of $D$. kaki as compared with medium with 6-benzyladenine (BA), kinetin, isopentenyl

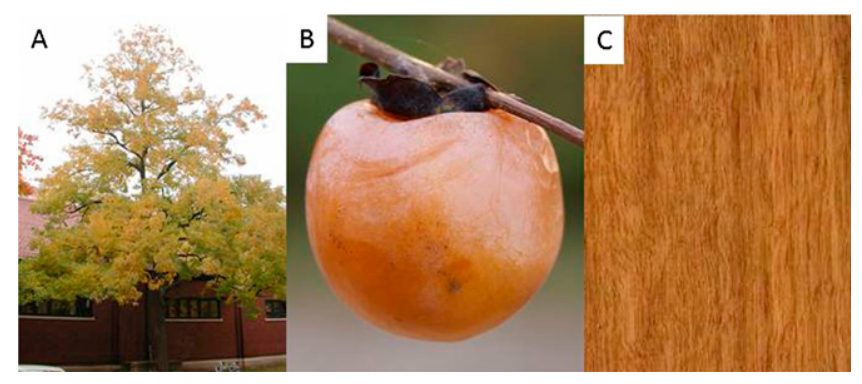

Fig. 1. Growth habit and fall color (A), fruit (B), and quarter-cut wood (C) of common persimmon (Diospyros virginiana L.). (A and B courtesy of Sally Weeks, Purdue University; C reprinted with permission from Russ Bork, Wood River Veneer, Gooding, ID; http://wood-veneer.com).
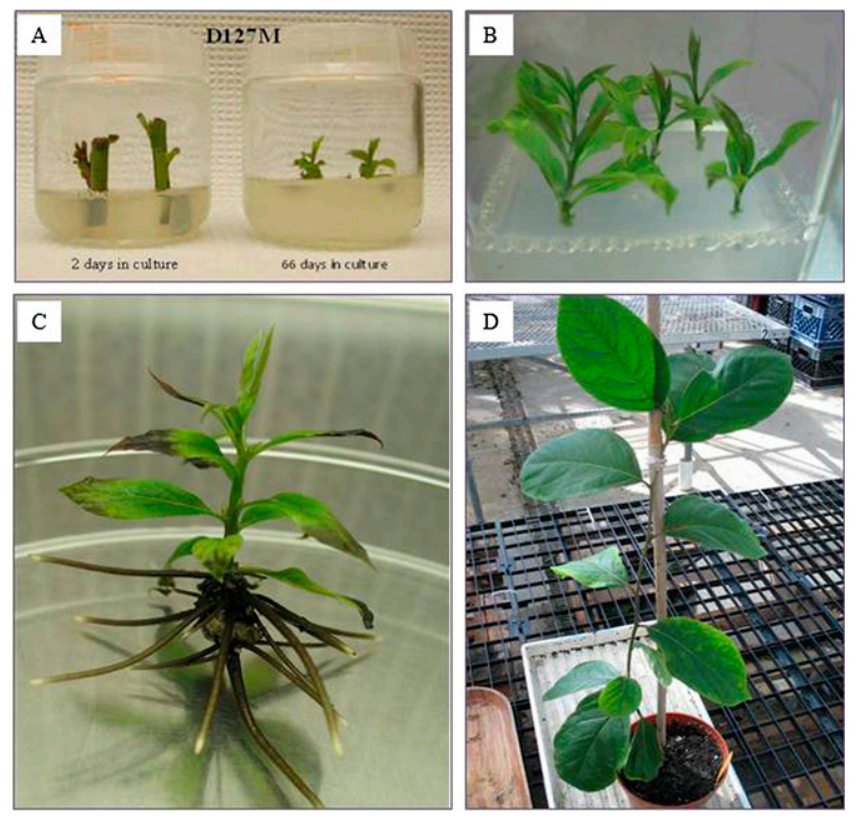

Fig. 2. In vitro propagation of common persimmon. Explant initiation (A), shoot elongation (B), in vitro rooted persimmon cultured on $5 \mu \mathrm{M}$ indole-3-butyric acid (IBA) (C), and acclimatized plant in the greenhouse (D).

adenine, or benzyl-tetrahydropyranyl-adenine. Fukui et al. (1992), using shoot tips from current growth, established shoot cultures of 95 Japanese persimmon cultivars and three other species $[D$. japonica, D. lotus (male), and $D$. virginiana (male and female)] on MS medium (half-strength nitrogen) plus $100 \mu \mathrm{M}$ zeatin. Tao and Sugiura (1992) established a protocol for $D$. kaki using dormant buds cultured on MS (half-strength nitrogen) medium with $20 \mu \mathrm{M}$ BA or $10 \mu \mathrm{M}$ zeatin. The authors noted that if cultures were initiated on $\mathrm{BA}$, those cultures needed to be transferred to $25 \mu \mathrm{M} 6-(\gamma, \gamma$-dimethylallylamino) purine (2iP) or $3 \mu \mathrm{M}$ zeatin to ensure shoot elongation and that some cultivars could not be established in vitro. In our study, continuous micropropagation through nodal sectioning of in vitro shoots of common persimmon was promoted by a reduction of zeatin to $5 \mu \mathrm{M}$ (Fig. 2B), a strategy that was proven effective for several $D$. kaki cultivars (Tetsumura and Yukinaga, 2000).

Rooting of microshoots occurred for all genotypes at all concentrations of IBA tested, but rooting was variable from genotype to genotype (Table 1). Rooting of genotype D127M (76\%; $3.2 \pm 1.5$ roots per shoot) and Claypool $\mathrm{H} 118(87 \% ; 3.9 \pm 0.7$ roots per shoot) responded the best overall to $5 \mu \mathrm{M}$ IBA (Fig. 2C). Golden Supreme produced the most rooting $(18.1 \%)$ on MS medium containing either $5 \mu \mathrm{M}(0.5 \pm 0.8$ roots per shoot $)$ or $15 \mu \mathrm{M}$ IBA $(1.3 \pm 1.2$ roots per shoot $)$. Szukis produced an average of $1.2 \pm 1.4$ roots per shoot and the hybrid 'Rosseyanka' produced $5.3 \pm 2.6$ roots per shoot on $10 \mu \mathrm{M}$ IBA. Ninety-one percent rooting was observed with the hybrid 'Rosseyanka' compared with only $16 \%$ with Szukis. Shoot tips of nine cultivars of Japanese persimmon cultured on medium containing $20 \mu \mathrm{M}$ BA rooted better than shoots from 23 cultivars cultured on $10 \mu \mathrm{M}$ zeatin (Tetsumura et al., 1991). Tao and Sugiura (1992) reported that Japanese persimmon shoots cultured on halfstrength MS medium (half-strength nitrogen), treated with $1.23 \mathrm{~mm}$ IBA for 15 to $30 \mathrm{~s}$, and then cultured in the dark on plant growth regulator-free medium for $9 \mathrm{~d}$ had the best rooting percent depending on the cultivar tested. An earlier report stated that Japanese 
Table 1. Effect of indole-3-butyric acid (IBA) on rooting of in vitro common persimmon shoots. ${ }^{\text {. }}$

\begin{tabular}{lcccc}
\hline Genotype IBA $(\mu \mathrm{M})$ & No. & Rooting $(\%)$ & No. roots per shoot & Root length $(\mathrm{cm})$ \\
\hline D127M & & & & \\
5 & 34 & $76.0 \pm 6.8 \mathrm{a}$ & $3.2 \pm 1.5 \mathrm{a}$ & $2.6 \pm 0.4 \mathrm{a}$ \\
10 & 34 & $53.1 \pm 8.8 \mathrm{ab}$ & $2.4 \pm 1.3 \mathrm{a}$ & $1.2 \pm 0.5 \mathrm{ab}$ \\
15 & 34 & $37.5 \pm 11.6 \mathrm{~b}$ & $2.6 \pm 2.0 \mathrm{a}$ & $0.9 \pm 0.4 \mathrm{~b}$ \\
Golden Supreme & & & & \\
5 & 26 & $18.1 \pm 13.7 \mathrm{a}$ & $0.5 \pm 0.8 \mathrm{a}$ & $0.5 \pm 0.4 \mathrm{a}$ \\
10 & 26 & $9.7 \pm 6.2 \mathrm{a}$ & $0.3 \pm 0.5 \mathrm{a}$ & $0.6 \pm 0.4 \mathrm{a}$ \\
15 & 26 & $18.1 \pm 5.9 \mathrm{a}$ & $1.3 \pm 1.2 \mathrm{a}$ & $0.9 \pm 0.4 \mathrm{a}$ \\
Szukis & & & & \\
5 & 38 & $13.5 \pm 5.2 \mathrm{a}$ & $0.9 \pm 1.1 \mathrm{a}$ & $0.9 \pm 0.5 \mathrm{a}$ \\
10 & 38 & $15.6 \pm 6.6 \mathrm{a}$ & $1.2 \pm 1.4 \mathrm{a}$ & $0.4 \pm 0.3 \mathrm{a}$ \\
15 & 38 & $8.9 \pm 4.8 \mathrm{a}$ & $1.1 \pm 1.5 \mathrm{a}$ & $0.1 \pm 0.1 \mathrm{a}$ \\
Claypool H118 & & & & \\
5 & 38 & $87.0 \pm 4.1 \mathrm{a}$ & $3.9 \pm 0.7 \mathrm{a}$ & $1.6 \pm 0.2 \mathrm{a}$ \\
10 & 38 & $66.7 \pm 8.3 \mathrm{ab}$ & $3.2 \pm 1.4 \mathrm{ab}$ & $1.0 \pm 0.9 \mathrm{ab}$ \\
15 & 38 & $44.8 \pm 8.9 \mathrm{~b}$ & $2.3 \pm 0.7 \mathrm{~b}$ & $0.6 \pm 0.4 \mathrm{~b}$ \\
Hybrid Rosseyanka & & & & \\
5 & 38 & $85.4 \pm 4.4 \mathrm{a}$ & $3.7 \pm 0.3 \mathrm{~b}$ & $2.2 \pm 0.1 \mathrm{a}$ \\
10 & 38 & $90.6 \pm 6.6 \mathrm{a}$ & $5.3 \pm 2.6 \mathrm{ab}$ & $2.1 \pm 0.2 \mathrm{a}$ \\
15 & 38 & $81.3 \pm 6.3 \mathrm{a}$ & $7.4 \pm 3.7 \mathrm{a}$ & $1.4 \pm 0.2 \mathrm{~b}$ \\
\hline
\end{tabular}

${ }^{2}$ Values represent means \pm SE for $\mathrm{N}$ explants per treatment. Means in each column followed by the same letter were not significantly different according to Duncan's multiple comparison test $(P \leq 0.05)$.

persimmon shoots rooted on higher IBA concentrations were weaker and some eventually died (Murayama et al., 1989). Tao and Sugiura (1992) also noted that shoots established using BA and then multiplied using $2 \mathrm{iP}$ or zeatin had higher rooting potential than shoots cultured on zeatin only, but many cultivars could only be established when using zeatin. Fukui et al. (1992) described variable rooting among $95 \mathrm{D}$. kaki cultivars $(0 \%$ to $100 \%)$ and two $D$. virginiana genotypes (60\% and $100 \%$; cultivars not reported) treated with $0.4 \% \alpha$-naphthyl acetamide and cultured on MS medium (half-strength nitrogen); 25 cultivars failed to root. Adventitious shoots, regenerated from in vitro root segments, of Japanese persimmon also rooted ( $0 \%$ to $100 \%$ depending on the cultivar) using a $1.25 \mathrm{~mm}$ IBA dip (Tetsumura and Yukinaga, 2000). Phloroglucinol has been shown to act synergistically with auxin, particularly IBA, and has a promotive effect on the rooting from several woody species, including Malus (James and Thurbon, 1981; Zimmerman, 1984) and Prunus (Hammatt, 1994; Jones and Hopgood, 1979). In the present study, $D$. virginiana nodal explants from four mature cultivars and one hybrid were established in vitro on MS medium with $10 \mu \mathrm{M}$ zeatin. Half-strength MS medium containing 5 to $15 \mu \mathrm{M}$ IBA promoted rooting, depending on the cultivar. Rooted plants of each genotype were successfully acclimatized to the greenhouse and showed normal growth and development (Fig. 2D). Future investigations will need to focus on scale-up in vitro propagation of these cultivars, improvement of rooting, and acclimatization of plants to the field.

\section{Literature Cited}

Coladonato, M. 1992. Diospyros virginiana. In: Fire Effects Information System [Online]. US Department of Agriculture, Forest Service, Rocky Mountain Research Station, Fire Sciences Laboratory (Producer). 8 Feb. 2012. <http://www.fs. fed.us/database/feis/>.

Cooper, P.A. and D. Cohen. 1985. Micropropagation of Japanese persimmon (Diospyros kaki). Proc. Intl. Plant Prop. Soc. 34:118-124.

Fukui, H., K. Nishimoto, and M. Nakamura. 1992. Varietal differences in rooting ability of in vitro subcultured Japanese persimmon shoots. J. Jpn. Soc. Hort. Sci. 60:821-825.

Fukui, H., M. Sugiyama, and M. Nakamura. 1989. Shoot tip culture of Japanese persimmon (Diospyros kaki Thunb.). J. Jpn. Soc. Hort. Sci. 58:43-47.

Halls, L.K. 1990. Diospyros virginiana L. common persimmon, p. 294-298. In: Burns, R.M. and B.H. Honkala (Tech coord.). Silvics of North America, Vol. 2, Hardwoods, Agric. Handbook 654. Washington, DC.

Hammatt, N. 1994. Promotion by phloroglucinol of adventitious root formation in micropropagated shoots of adult wild cherry (Prunus avium L.). Plant Growth Regulat. 14:127-132.

James, D.J. and I.J. Thurbon. 1981. Shoot and root initiation in vitro in the apple rootstock M.9 and the promotive effects of phloroglucinol. J. Hort. Sci. 56:15-20.

Jones, O.P. and M.E. Hopgood. 1979. The successful propagation in vitro of two rootstocks of Prunus: The plum rootstock Pixy (P. insititia) and the cherry rootstock F12/1 ( $P$. avium). J. Hort. Sci. 54:63-66.

Morton, J.F. 1987. Japanese Persimmon. Diospyros kaki L, p. 411-416. In: Fruits of warm climates. Creative Resource Systems, Inc., Winterville, NC. 4 Sept. 2012. <http://www.hort.purdue. edu/newcrop/morton/japanese_persimmon. html>.

Murashige, T. and F. Skoog. 1962. A revised medium for rapid growth and bio assays with tobacco tissue culture. Physiol. Plant. 15:473497.

Murayama, H., R. Tao, T. Tanaka, and A. Sugiura. 1989. In vitro shoot proliferation and rooting of several Japanese persimmon cultivars. J. Jpn. Soc. Hort. Sci. 58:55-61.

SPSS, Inc.. 2009. SPSS for Windows, Version 17. SPSS, Inc., Chicago, IL.

Tao, R. and A. Sugiura. 1992. Micropropagation of Japanese persimmon (Diospyros kaki L.), p. 424-440. In: Bajaj, Y.P.S. (ed.). Biotechnology in agriculture and forestry. SpringerVerlag, Berlin, Heidelberg, Germany.

Tetsumura, T., R. Tao, and A. Sugiura. 1991 Effect of cytokinin types on the in vitro propagation of Japanese persimmon (Diospyros kaki Thunb.). Plant Tissue Cult. Lett. 8:209-211.

Tetsumura, T. and H. Yukinaga. 2000. Comparative rooting of shoot tips of four Japanese persimmon cultivars vs. shoots regenerated from roots cultured in vitro. HortScience 35:940-944

Zimmerman, R.H. 1984. Rooting apple cultivars in vitro: Interactions among light, temperature, phloroglucinol and auxin. Plant Cell Tiss. Org. Cult. 3:301-311. 